\title{
An optimized pathway for phosphate ions removal from aqueous solution based on experimental design methodology
}

\author{
E. Zran • B. Yao • A. Trokourey • A. Yobouet • \\ P. Drogui
}

Received: 13 February 2014/Revised: 28 October 2014/Accepted: 9 December 2014/Published online: 23 December 2014

(C) Islamic Azad University (IAU) 2014

\begin{abstract}
Wastewaters can contain residual phosphorus concentrations above the recommended limiting values, and it could have a high environmental impact. The discharge of such effluents is undesirable and can cause excessive nutrients and eutrophication in the receiving water. In order to produce an effluent suitable for stream discharge, chemical precipitation of phosphate based on a sequential experimental design has been explored. The influence of factors [pH, type of salt (calcium or iron)] involved in the co-precipitation of phosphate ions was studied by a complete factorial design. It was established that the optimal parameter values obtained from a secondorder model allowed conclusion to be drawn on the effectiveness of the removal. So in the best conditions $(\mathrm{pH}$ 8.41 and a dose of $97.07 \mathrm{mg} / \mathrm{L} \mathrm{Ca}(\mathrm{OH})_{2}$ with $10 \mathrm{mg} / \mathrm{L}$ $\mathrm{FeSO}_{4} \cdot 7 \mathrm{H}_{2} \mathrm{O}$ ), $95.80 \%$ (removal rate) of the phosphate ion were removed from the synthetic solution. A second-order
\end{abstract}

Electronic supplementary material The online version of this article (doi:10.1007/s13762-014-0738-1) contains supplementary material, which is available to authorized users.

E. Zran $\cdot$ B. Yao $\cdot$ A. Yobouet

Laboratoire de Procédés Industriels, de Synthèse, de

l'Environnement, et des Energies Nouvelles, Groupe des

Procédés et Environnement, Institut National Polytechnique

Félix Houphouët-Boigny, B.P. 1093, Yamoussoukro, Côte

d'Ivoire

A. Trokourey

Laboratoire de Chimie Physique, Université de Cocody-Abidjan

(UFR-SSMT), 22, B.P. 582, Abidjan 22, Côte d'Ivoire

\section{P. Drogui $(\bowtie)$}

Institut National de la Recherche Scientifique (INRS-Eau Terre

et Environnement), Université du Quebec, 490 rue de la

Couronne, Quebec, QC G1K 9A9, Canada

e-mail: patrick.drogui@ete.inrs.ca mathematical model of the removal of phosphate ions, depending on two parameters which are $\mathrm{pH}$ and $\mathrm{Ca}(\mathrm{OH})_{2}$ concentration, was finally proposed. Moreover, on the basis on the $\mathrm{pH}$ solution, it was shown that the precipitate formed was hydroxyapatite $\mathrm{Ca}_{10}\left(\mathrm{PO}_{4}\right)_{6}(\mathrm{OH})_{2}$ and the scanning electron microscopy views revealed the amorphous and homogeneous aspect of the precipitates.

Keywords Eutrophication - Phosphate ions - Response surface methodology · Factorial design co-precipitation . Removal rate

\section{Introduction}

Eutrophication is the process by which a body of water acquires a high concentration of nutrients, especially phosphates and nitrates. The invading aquatic plants constitute one of the major problems that threaten the aquatic life in the rivers and lakes. The lakes, object of eutrophication phenomenon, present varied trophic answers although supplied with the same water origin. The harmful effects of the proliferation of the aquatic plants (algae and macrophytes) contribute to the filling of the wells located in alluvial table cloths and disturb the normal fish life. This phenomenon generally affects the stagnant masses of water or with renewal seems to be an ecological problem with an economic implication (Biernaux 1979; Mama et al. 2003). One possible way to fight against this phenomenon, whose disastrous effect on aquatic ecosystems is well known, remains the treatment of wastewater, including phosphorus removal prior to discharge into the environment. Even though the causes of eutrophication are diverse, it can be noted that exogenous causes related to human activities are the main ones. For example, the massive use of detergents, 
chemical fertilizers, and inadequate treatment of sewage sludge sanitation contribute to increase sharply, pollutant loads of phosphate ions in wastewater. There are various methods for removing dissolved phosphorus from aqueous solutions (Roques 1990; GLS 2006; CEMAGREF 2004). The physicochemical processes used are based on phenomena of precipitation and adsorption, in general by using calcium, iron or aluminum salts. Phosphate removal can also be achieved by biological processes. However, physicochemical methods of phosphate removal studied by several authors remain the most effective and reliable (Montastruc 2003; Barbara and Jaroslaw 2005; Youcef and Achour 2005; Battistoni et al. 2006; Lupa et al. 2008; Cordell et al. 2009; Del Nero et al. 2010; Hanhoun et al. 2011; Shintaro and Keisuke 2012; Said Metahri 2012).

This study aims in particular two main contributions. It is firstly to determine the optimum conditions of implementation of the co-precipitation of phosphate and to establish a mathematical model that can facilitate the future industrial processes development. For this purpose, sequential experimental design methods, which are statistical tools for analysis, making it possible to highlight the relations between the parameters and their effects on a phenomenon studied (a removal rate for instance), were used. These methods allow minimizing the numbers of runs to be carried out to make the study.

\section{Materials and methods}

Preparation of synthetic solutions

The water samples used throughout this study were prepared synthetically by dissolving potassium dihydrogenphosphate $\left(\mathrm{KH}_{2} \mathrm{PO}_{4}\right.$, ACS analytical grade reagent, NY, USA) in tap water to reach a concentration of $10 \mathrm{mg} / \mathrm{L}$. Mixing and stirring time of $10 \mathrm{~min}$ was required to completely dissolve $\mathrm{KH}_{2} \mathrm{PO}_{4}$ prior to the chemical treatment of the synthetic solution.

Removal procedure of phosphate ions from synthetic solutions

The synthetic solution was treated using either iron (II) sulfate heptahydrate $\left(\mathrm{FeSO}_{4} \cdot 7 \mathrm{H}_{2} \mathrm{O}\right)(\mathrm{Fe}$ content $20.1 \% \mathrm{w} / \mathrm{w}$ basis provided by ACS analytical grade reagent, NY, USA company) or iron (III) chloride hexahydrate $\left(\mathrm{FeCl}_{3} \cdot 6 \mathrm{H}_{2} \mathrm{O}\right)$ (Fe content $20.7 \%$ w/w basis provided by ACS analytical grade reagent, NY, USA company) and by simultaneously using calcium salts. Calcium salts were used either in the form of calcium hydroxide $\left(\mathrm{Ca}(\mathrm{OH})_{2}\right)$ or in the form of calcium chloride $\left(\mathrm{CaCl}_{2}\right)$. Experiments were carried out in a 500-mL tank (Pyrex glass) containing $200 \mathrm{~mL}$ of synthetic solution that was mixed using a jar-test system. Different concentrations of iron salts $\left(\mathrm{FeSO}_{4} \cdot 7 \mathrm{H}_{2} \mathrm{O}\right.$ or $\mathrm{FeCl}_{3} \cdot 6 \mathrm{H}_{2} \mathrm{O}$ ) ranging from 10 to $50 \mathrm{mg} / \mathrm{L}$ were tested. Calcium salt $\left(\mathrm{Ca}(\mathrm{OH})_{2}\right.$ or $\left.\mathrm{CaCl}_{2}\right)$ concentrations varied from 80 to $97 \mathrm{mg} / \mathrm{L}$. Fe and Ca doses were selected based on the preliminary tests and based on the literature (Lupa et al. 2008; Youcef and Achour 2005). The mixture was firstly stirred at $150 \mathrm{rpm}$ during $3 \mathrm{~min}$, followed by a $30-$ min stirring under $30 \mathrm{rpm}$. After $33 \mathrm{~min}$ of treatment, the mixture was subjected to settling for $1 \mathrm{~h}$. Once the separation of metallic sludge occurred $(1 \mathrm{~h})$, a fraction of the supernatant was recovered for $\mathrm{pH}$ and residual phosphorus concentration analysis. The residual phosphate concentration was used to calculate the removal rate according to Eq. (1):

Removal rate $(\%)=\frac{C_{0}-C_{1}}{C_{0}} \times 100$

with $C_{0}=10 \mathrm{mg} / \mathrm{L}$ and $C_{1}$ residual quantities of phosphate ions.

\section{Design of statistical experiments}

A sequential approach based on the experimental design (particularly complete factorial design, FD) was used for the study. So, to begin with, a screening on the type of salt to obtain the best rate of phosphate ions removal was carried out. Experiments were designed to find the interaction of three variables, i.e., $\mathrm{pH}$, nature of calcium salt and iron salt. Table 1 shows the coded and uncoded values of the variables taking into account in the factorial design $\left(2^{k}\right)$. Experiments for first set were designed to find the interaction of three variables, i.e., $\mathrm{pH}$, nature of calcium salt and iron salt. Then, the second set of experiments was carried out by considering the concentration of salts as numerical variables. Subsequently, a central composite design (CCD) was employed to describe the process in the experimental domain and also for the optimization of the chemical process to have the best removal of phosphate. The experimental region investigated for phosphate removal and the coded values are shown in Table 1 . The independent process variables investigated were $\mathrm{pH}\left(U_{1}\right)$, the type or the concentration of calcium salts $\left(U_{2}\right)$ and the type or the concentration of iron salts $\left(U_{3}\right)$. The removal efficiency of phosphate was considered as the response (Y). The levels of different factors were selected based on the preliminary assays. The experimental values of $U_{i}$ can be calculated from the coded variables $X_{i}$ using the following equation: 
Table 1 Data for optimization operation: experimental range and levels of independent process variables

\begin{tabular}{|c|c|c|c|c|c|}
\hline \multirow[t]{2}{*}{ Coded variables $\left(X_{i}\right)$} & \multirow[t]{2}{*}{ Factors $\left(U_{i}\right)$} & \multicolumn{2}{|c|}{ Experimental field } & \multirow[t]{2}{*}{$U_{i, 0}$} & \multirow[t]{2}{*}{$\Delta U_{i}$} \\
\hline & & Min value $(-1)$ & Max value $(+1)$ & & \\
\hline \multicolumn{6}{|c|}{ First set of experiments } \\
\hline$X_{1}$ & $U_{1}: \mathrm{pH}$ & 5 & 10 & 7.5 & 2.5 \\
\hline$X_{2}$ & $U_{2}:$ Calcium salts & $\mathrm{CaCl}_{2}$ & $\mathrm{Ca}(\mathrm{OH})_{2}$ & - & - \\
\hline$X_{3}$ & $U_{3:}$ Iron salts & $\mathrm{FeSO}_{4} \cdot 7 \mathrm{H}_{2} \mathrm{O}$ & $\mathrm{FeCl}_{3} \cdot 6 \mathrm{H}_{2} \mathrm{O}$ & - & - \\
\hline \multicolumn{6}{|c|}{ Second set of experiments } \\
\hline$X_{1}$ & $U_{1}: \mathrm{Ph}$ & 7.0 & 9.0 & 8 & 1.0 \\
\hline$X_{2}$ & $U_{2}: \mathrm{Ca}(\mathrm{OH})_{2} \mathrm{mg} / \mathrm{L}$ & 80 & 90 & 85 & 5.0 \\
\hline$X_{3}$ & $U_{3}: \mathrm{FeSO}_{4} \cdot 7 \mathrm{H}_{2} \mathrm{O}$, in $\mathrm{mg} / \mathrm{L}$ & 10 & 20 & 15 & 5.0 \\
\hline
\end{tabular}

$X_{i}=\frac{U_{i}-U_{i, 0}}{\Delta U_{i}}$

where $U_{i, 0}=\left(U_{i, \max }+U_{i, \min }\right) / 2$ represents the value of $U_{i}$ at the center of the experimental field and $\Delta U_{i, 0}=$ $\left(U_{i, \max }-U_{i, \min }\right) / 2$ represents the step of the variation, with $U_{i, \max }$ and $U_{i, \min }$ which are the maximum and minimum values of the effective variable $U_{i}$, respectively. The main interactions, correlation coefficients, variance analysis, residual, standard deviation were performed by using the NEMROD-W program software (design NEMROD-W, version 9901 Française LPRAI-Marseille Inc, France) (Goupy 2006). All the experiments were duplicated in order to estimate the variability of measurements.

Analytical techniques

The $\mathrm{pH}$ was determined using a $\mathrm{pH}$ meter $(\mathrm{pH}$ meter HANNA HI 98150 GLP pH/ORP METER) equipped with electrode HI 1618 [smart electrode with built-in temperature sensor, DIN connector and 1-m (3.3') cable]. To determine dissolved phosphorus concentrations, the samples were first filtered on Whatman glass microfiber filters (GF/C circles $55 \mathrm{~mm}$ diameter) under vacuum. Phosphate concentrations were determined by using a spectrophotometer (JASCO V-530 UV-Vis, Japan) (AFNOR 1994).

\section{Results and discussion}

Effects of the experimental parameters on the phosphate removal using the experimental factorial design methodology

The influence of different variables- $\mathrm{pH}\left(U_{1}\right)$, type of calcium salts $\left(U_{2}\right)$ and type of iron salts $\left(U_{3}\right)$ on the
Table 2 Experimental factorial matrix in the $2^{3}$ design for calculation of effects for the first set of experiments

\begin{tabular}{|c|c|c|c|c|c|c|c|}
\hline \multirow{3}{*}{$\begin{array}{l}\text { No } \\
\text { exp. }\end{array}$} & \multicolumn{6}{|c|}{ Factors } & \multirow{3}{*}{$\begin{array}{l}\text { Phosphate } \\
\text { removal (\%) }\end{array}$} \\
\hline & \multicolumn{3}{|c|}{$\begin{array}{l}\text { Coded } \\
\text { variables }\end{array}$} & \multicolumn{3}{|c|}{ Real variables } & \\
\hline & $X_{1}$ & $X_{2}$ & $X_{3}$ & $\mathrm{pH}$ & $\begin{array}{l}\text { Calcium } \\
\text { salts }\end{array}$ & Iron salts & \\
\hline 1 & -1 & -1 & -1 & 5 & $\mathrm{CaCl}_{2}$ & $\mathrm{FeSO}_{4} \cdot 7 \mathrm{H}_{2} \mathrm{O}$ & 10.00 \\
\hline 2 & +1 & -1 & -1 & 10 & $\mathrm{CaCl}_{2}$ & $\mathrm{FeSO}_{4} \cdot 7 \mathrm{H}_{2} \mathrm{O}$ & 75.00 \\
\hline 3 & -1 & +1 & -1 & 5 & $\mathrm{Ca}(\mathrm{OH})_{2}$ & $\mathrm{FeSO}_{4} \cdot 7 \mathrm{H}_{2} \mathrm{O}$ & 70.00 \\
\hline 4 & +1 & +1 & -1 & 10 & $\mathrm{Ca}(\mathrm{OH})_{2}$ & $\mathrm{FeSO}_{4} \cdot 7 \mathrm{H}_{2} \mathrm{O}$ & 75.00 \\
\hline 5 & -1 & -1 & +1 & 5 & $\mathrm{CaCl}_{2}$ & $\mathrm{FeCl}_{3} \cdot 6 \mathrm{H}_{2} \mathrm{O}$ & 15.00 \\
\hline 6 & +1 & -1 & +1 & 10 & $\mathrm{CaCl}_{2}$ & $\mathrm{FeCl}_{3} \cdot 6 \mathrm{H}_{2} \mathrm{O}$ & 10.00 \\
\hline 7 & -1 & +1 & +1 & 5 & $\mathrm{Ca}(\mathrm{OH})_{2}$ & $\mathrm{FeCl}_{3} \cdot 6 \mathrm{H}_{2} \mathrm{O}$ & 60.00 \\
\hline 8 & +1 & +1 & +1 & 10 & $\mathrm{Ca}(\mathrm{OH})_{2}$ & $\mathrm{FeCl}_{3} \cdot 6 \mathrm{H}_{2} \mathrm{O}$ & 75.00 \\
\hline
\end{tabular}

$\left[\mathrm{Ca}(\mathrm{OH})_{2}\right]=\left[\mathrm{CaCl}_{2}\right]=80.00 \mathrm{mg} / \mathrm{L} \quad$ and $\quad\left[\mathrm{FeSO}_{4} \cdot 7 \mathrm{H}_{2} \mathrm{O}\right]=$ $\left[\mathrm{FeCl}_{3} \cdot 6 \mathrm{H}_{2} \mathrm{O}\right]=50.00 \mathrm{mg} / \mathrm{L}$

phosphate removal during the first set of experimentswas investigated using factorial matrix $\left(2^{k}, k\right.$ being the number of factors). Table 2 illustrated the results obtained. The calculated standard deviation on the response, about 28.88 , shows that the experimental field is well chosen. From this Table 2, it can be seen that the best performance of phosphate removal $(75 \%$ of phosphate removal) was recorded at $\mathrm{pH} 10$ using $\mathrm{Ca}(\mathrm{OH})_{2}$ combined with either $\mathrm{FeSO}_{4} \cdot 7 \mathrm{H}_{2} \mathrm{O}$ or $\mathrm{FeCl}_{3} \cdot 6 \mathrm{H}_{2} \mathrm{O}$. Likewise, $75 \%$ of phosphate removal was reached while using $\mathrm{CaCl}_{2}$ in the presence of $\mathrm{FeSO}_{4} \cdot 7 \mathrm{H}_{2} \mathrm{O}$. The $2^{3}$ factorial design allows us to calculate the principle effect of each factor and the interaction between them and to write a linear polynomial model with interactions, as follows (Eq. 3): 
Fig. 1 Graphical Pareto analysis of the effect of $\mathrm{pH}$, type of calcium salts and type of iron salts

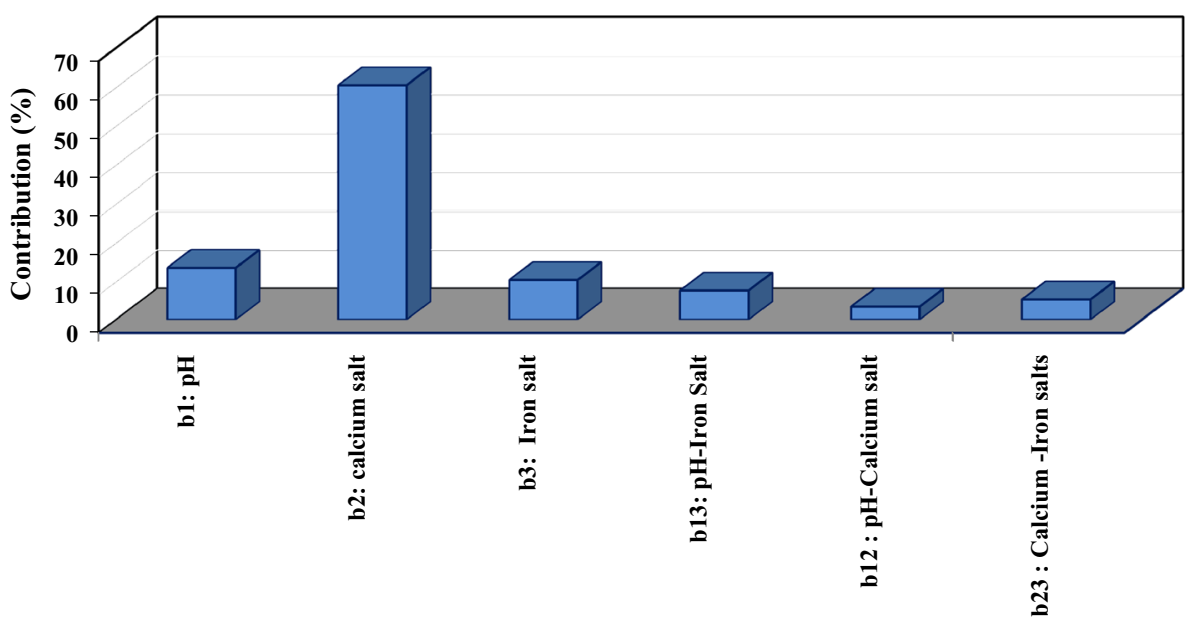

$Y=b_{0}+b_{1} X_{1}+b_{2} X_{2}+b_{3} X_{3}+b_{12} X_{1} X_{2}+b_{13} X_{1} X_{3}$ $+b_{23} X_{2} X_{3}$

where Y represents the experimental response (i.e., the removal rate of phosphate ion), $b_{1}, b_{2}$ and $b_{3}$ represent the principal effects associated with the factor $X_{1}, X_{2}$ and $X_{3}$, and $b_{12}, b_{13}$ and $b_{23}$ represent the interaction effect between the corresponding factors. The coefficients of the model were calculated using the half difference between the arithmetic average of the response values when the associated coded variable is at a level $(+1)$ and the arithmetic average of the response values when the associated coded variable is at level $(-1)$. Design NEMROD-W ${ }^{\circledR}$ program software (design NEMROD-W, version 9901 LPRAI-Marseille Inc, France) was used to calculate the coefficient of the polynomial model (Eq. 4).

$$
\begin{aligned}
Y= & 48.75+10 X_{1}+21.25 X_{2}-8.75 X_{3}-5 X_{1} X_{2} \\
& -7.5 X_{1} X_{3}+6.25 X_{2} X_{3}
\end{aligned}
$$

The value of the regression coefficient $R^{2}$ was 0.88 . The coefficient $b_{0}=48.75$ represents the average value of the response of eight assays. From Eq. (4), it can be seen that the removal of phosphate is strongly influenced by the type of calcium salt $\left(b_{2}=+21.25\right)$ which has positive effect on the studied response. From a statistics point of view, the percentage of phosphate removal increases of $42.5 \%$ $(2 \times 21.25)$ when $\mathrm{Ca}(\mathrm{OH})_{2}$ is used, instead of $\mathrm{CaCl}_{2}$. This observation is consistent with the data recorded by (Jane Huang and Liu 1999). It seems that the presence of chloride ions constitutes a limiting factor as shown by Frederick (Walter 2010). The second most important factor on the removal of phosphate is the $\mathrm{pH}$ with a positive effect $\left(b_{1}=+10\right)$. The increase in $\mathrm{pH}$ contributes to increase the

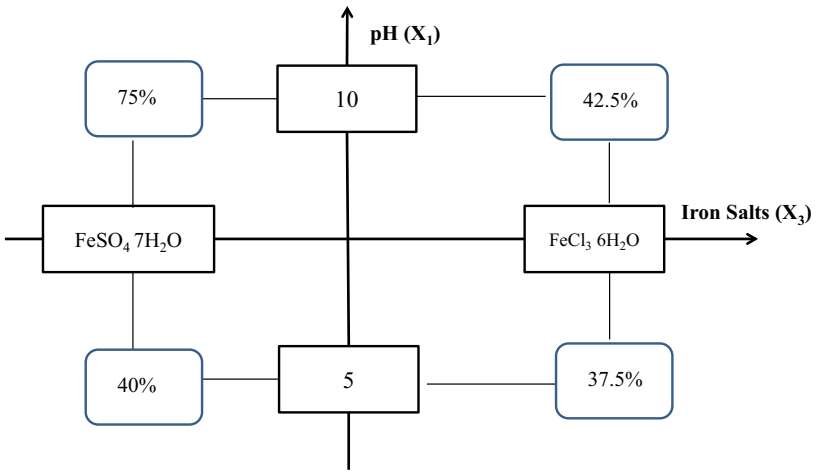

Fig. 2 Interaction $\times 13$ between $\mathrm{pH}$ and the type of iron salts

phosphate removal rate of $20 \%$. Concerning the effect of iron salt $\left(b_{3}=-8.75\right)$, it can be noted that the percentage of phosphate removal decreases of $17.5 \%(2 \times 8.75)$ when the experiments were carried out with $\mathrm{FeCl} 3 \cdot 6 \mathrm{H} 2 \mathrm{O}$ instead of $\mathrm{FeSO} 4.7 \mathrm{H} 2 \mathrm{O}$, in accordance with the observation of Lupa et al. (2008). The importance of the factors and interactions on phosphate removal has been put into evidence using Eq. (5). Indeed, it is possible to give more significant information by calculating the contribution of each factor on the response.

$P_{i}=\left(\frac{b_{i}^{2}}{\sum b_{i}^{2}}\right) * 100 \quad(i \neq 0)$

where bi represents the estimation of the principal effect of the factor i. Figure 1 highlights the contribution of the type of calcium salts, $\mathrm{pH}$ and the type of iron salts on phosphate removal that are $60.2,13.4$ and $10.2 \%$, respectively. Regarding the interaction effects, they were globally weaker than the main effects. The most important is the 
$X_{1} X_{3}$ with a value $b_{13}=-7.5$. The analysis of this interaction can be greatly facilitated by considering the Fig. 2 . Each apex represents the average value of the responses obtained under the same experimental conditions. When the type of anode $\left(X_{3}\right)$ is fixed at the highest level $(\mathrm{FeCl} 3.6 \mathrm{H} 2 \mathrm{O})$, the $\mathrm{pH}$ has not a significant effect on the rate of phosphate removal. The rate of phosphate removal passed from 37.5 to $42.5 \%$ (a removal gain of five units). When the type of iron salt is fixed at the lowest level (FeSO4.7H2O), the removal rate passed from 40 to $75 \%$ (a removal gain of 35 units). Consequently, the effect of $\mathrm{pH}$ is dependent on the type of iron used. Thus, the most important effect is achieved by using $\mathrm{FeSO} \cdot 7 \mathrm{H} 2 \mathrm{O}$.

According to results discussed above, a new experimental field taking into account only the calcium salt $\mathrm{FeSO}_{4} \cdot 7 \mathrm{H}_{2} \mathrm{O}, \mathrm{Ca}(\mathrm{OH})_{2}$ was defined (a second set of experiments) in order to deeply examine the combined effect of the three previous variables, i.e., the $\mathrm{pH}\left(U_{1}\right)$, calcium hydroxyl concentration $\left(U_{2}\right)$ and iron sulfate hexahydrate concentration $\left(U_{3}\right)$. The experimental results are presented in Table 3. It can be seen that the phosphate removal varied from 93 to $96 \%$. There is a small variation in the removal of the phosphate ion. This is also confirmed by the standard deviation of the response whose value is very low (0.747). The statistics of the coefficient are exhibited in SM1 and allow conclusion to be drawn on the influence of each parameter. From SM2, only $b_{2}$ is significant, since its value is higher than twice the standard deviation. The high value of $b_{0}(94.465)$ attests to the

Table 3 Experimental factorial matrix in the $2^{3}$ design for calculation of effects for the second set of experiments

\begin{tabular}{|c|c|c|c|c|c|c|c|}
\hline \multirow{3}{*}{$\begin{array}{l}\text { No } \\
\text { exp. }\end{array}$} & \multicolumn{6}{|c|}{ Factors } & \multirow{3}{*}{$\begin{array}{l}\text { Phosphate } \\
\text { removal (\%) }\end{array}$} \\
\hline & \multicolumn{3}{|c|}{$\begin{array}{l}\text { Coded } \\
\text { variables }\end{array}$} & \multicolumn{3}{|c|}{ Real variables } & \\
\hline & $X_{1}$ & $X_{2}$ & $X_{3}$ & $\mathrm{pH}$ & $\begin{array}{l}\text { Dose of } \\
\mathrm{Ca}(\mathrm{OH})_{2}\end{array}$ & $\begin{array}{l}\text { Dose of } \\
\mathrm{FeSO}_{4} \cdot 7 \mathrm{H}_{2} \mathrm{O}\end{array}$ & \\
\hline 1 & -1 & -1 & -1 & 7 & 80.00 & 10.00 & 94.55 \\
\hline 2 & +1 & -1 & -1 & 9 & 80.00 & 10.00 & 94.55 \\
\hline 3 & -1 & +1 & -1 & 7 & 90.00 & 10.00 & 95.45 \\
\hline 4 & +1 & +1 & -1 & 9 & 90.00 & 10.00 & 95.45 \\
\hline 5 & -1 & -1 & +1 & 7 & 80.00 & 20.00 & 94.55 \\
\hline 6 & +1 & -1 & +1 & 9 & 80.00 & 20.00 & 92.73 \\
\hline 7 & -1 & +1 & +1 & 7 & 90.00 & 20.00 & 95.45 \\
\hline 8 & +1 & +1 & +1 & 9 & 90.00 & 20.00 & 94.55 \\
\hline 9 & 0 & 0 & 0 & 8 & 85.00 & 15.00 & 93.64 \\
\hline 10 & 0 & 0 & 0 & 8 & 85.00 & 15.00 & 93.64 \\
\hline 11 & 0 & 0 & 0 & 8 & 85.00 & 15.00 & 94.55 \\
\hline
\end{tabular}

validity of all the conclusions drawn previously. About $94 \%$ of the phosphates ions are removed from the synthetic solution. The polynomial model that emerges from the second factorial design is illustrated by Eq. (6).

$$
\begin{aligned}
Y= & 94.465-0.34 X_{1}+0.565-0.34 X_{3}+0.115 X_{1} X_{2} \\
& -0.34 X_{1} X_{3}+0.115 X_{2} X_{3}
\end{aligned}
$$

Optimization condition for phosphate removal using central composite design methodology

The use of complete factorial design (second set of experiment) assumes that the model is linear. This hypothesis is not sufficiently pertinent while considering the correlation coefficient that is 0.771 . Consequently, a nonlinear model, a composite design methodology was proposed (Table 4). The central composite matrix is comprised of three sets: factorial matrix (assays 1-4), star matrix (assays 5-8) and a set of point at the center of the experimental domain (assays 9-13). A total of thirteen experiments were required for response surface modeling. Finally, the experimental response is represented by a nonlinear polynomial model (Eq. 7), as follows:

$$
\begin{aligned}
Y\left(X_{1}, X_{2}\right) 10^{3}= & 94360+636 X_{1}+313 X_{2}-155 X_{2}^{2}-55 X_{2}^{2} \\
& +300 X_{1} X_{2}
\end{aligned}
$$

\begin{tabular}{|c|c|c|c|c|c|}
\hline \multirow{3}{*}{$\begin{array}{l}\text { No } \\
\text { exp. }\end{array}$} & \multicolumn{4}{|l|}{ Factors } & \multirow{3}{*}{$\begin{array}{l}\text { Phosphate removal } \\
(\%)\end{array}$} \\
\hline & \multicolumn{2}{|c|}{$\begin{array}{l}\text { Coded } \\
\text { variables }\end{array}$} & \multicolumn{2}{|c|}{ Real variables } & \\
\hline & $X_{1}$ & $X_{2}$ & $\mathrm{pH}$ & $\begin{array}{l}\text { Dose of } \\
\mathrm{Ca}(\mathrm{OH})_{2} \\
(\mathrm{in} \mathrm{mg} / \mathrm{L})\end{array}$ & \\
\hline 1 & -1 & -1 & 6.00 & 85.00 & 93.40 \\
\hline 2 & 1 & -1 & 8.00 & 85.00 & 94.00 \\
\hline 3 & -1 & 1 & 6.00 & 95.00 & 93.70 \\
\hline 4 & 1 & 1 & 8.00 & 95.00 & 95.50 \\
\hline 5 & -1.41 & 0 & 5.59 & 90.00 & 93.10 \\
\hline 6 & +1.41 & 0 & 8.41 & 90.00 & 95.00 \\
\hline 7 & 0 & -1.41 & 7.00 & 82.93 & 94.00 \\
\hline 8 & 0 & +1.41 & 7.00 & 97.07 & 94.50 \\
\hline 9 & 0 & 0 & 7.00 & 90.00 & 94.30 \\
\hline 10 & 0 & 0 & 7.00 & 90.00 & 94.40 \\
\hline 11 & 0 & 0 & 7.00 & 90.00 & 94.40 \\
\hline 12 & 0 & 0 & 7.00 & 90.00 & 94.30 \\
\hline 13 & 0 & 0 & 7.00 & 90.00 & 94.40 \\
\hline
\end{tabular}

A model is assumed to be good if the sum of squares due to residuals (i.e., to fit error) is $<33.33 \%$

Table 4 Central composite matrix and experimental results 
Table 5 ANOVA results for the response surface quadratic model for phosphate removal

\begin{tabular}{lccccc}
\hline $\begin{array}{l}\text { Source of } \\
\text { variation }\end{array}$ & $\begin{array}{l}\text { Sum of } \\
\text { squares }\end{array}$ & $\begin{array}{l}\text { Degrees of } \\
\text { freedom }\end{array}$ & $\begin{array}{l}\text { Mean } \\
\text { square }\end{array}$ & Report & Signif. \\
\hline Regression & 4.5561 & 5 & 0.9112 & 303.7397 & $* * *$ \\
Residue & 0.1716 & 7 & 0.0245 & & \\
Validity & 0.1596 & 3 & 0.0532 & 17.7330 & $*$ \\
Error & 0.0120 & 4 & 0.0030 & & \\
Total & 4.7277 & 12 & & & \\
\hline
\end{tabular}

Table 6 Comparison of actual values $\left(Y_{\text {exp. }}\right)$ and calculated $\left(Y_{\text {calc. }}\right)$ values

\begin{tabular}{lllc}
\hline No exp. & $Y_{\text {exp. }}$ & $Y_{\text {calc. }}$ & Relative deviation \\
\hline 1 & 93.400 & 93.501 & -0.101 \\
2 & 94.000 & 94.172 & -0.172 \\
3 & 93.700 & 93.528 & 0.172 \\
4 & 95.500 & 95.399 & 0.101 \\
5 & 93.100 & 93.151 & -0.051 \\
6 & 95.000 & 94.949 & 0.051 \\
7 & 94.000 & 93.807 & 0.193 \\
8 & 94.500 & 94.693 & -0.193 \\
9 & 94.300 & 94.360 & -0.060 \\
10 & 94.400 & 94.360 & 0.040 \\
11 & 94.400 & 94.360 & 0.040 \\
12 & 94.300 & 94.360 & -0.060 \\
13 & 94.400 & 94.360 & 0.040 \\
\hline
\end{tabular}

of the sum of squares due to the regression [19]. In addition, the analysis of variance (ANOVA) shows that the sum of squares due to error is very low $(0.25 \%)$ to the total (Table 5). The model is fitted so well. The comparisons of experimental ( $\left.Y_{\text {exp. }}\right)$ and predicted values $\left(Y_{\text {calc }}\right)$ of phosphate removal are listed in Table 6 and represented in SM3. The low relative deviation values recorded (between the experimental and predicted values) indicate that second-order polynomial model described by Eq. (7) is satisfactory. It can be noted that the residuals (the difference between the measured response) ( $\left.Y_{\text {exp. }}\right)$ and the predicted responses from the fitted model $\left(Y_{\text {calc. }}\right)$ did not exceed $5 \%$ (Feinberg 1996). Likewise, the model can be represented by the response surface and contour plot (Fig. 3). In the figure, Y, $X_{1}$ and $X_{2}$ represent the removal rate $(\%), \mathrm{pH}$ and $\mathrm{Ca}(\mathrm{OH})_{2}$ concentration $(\mathrm{mg} /$ $\mathrm{L})$, respectively. Finally, $\mathrm{Ca} / \mathrm{P}$ and $\mathrm{Fe} / \mathrm{P}$ molar ratios determined in the optimal conditions are the following: $\mathrm{Fe} / \mathrm{P}=0.34$ and $\mathrm{Ca} / \mathrm{P}=12.5$.

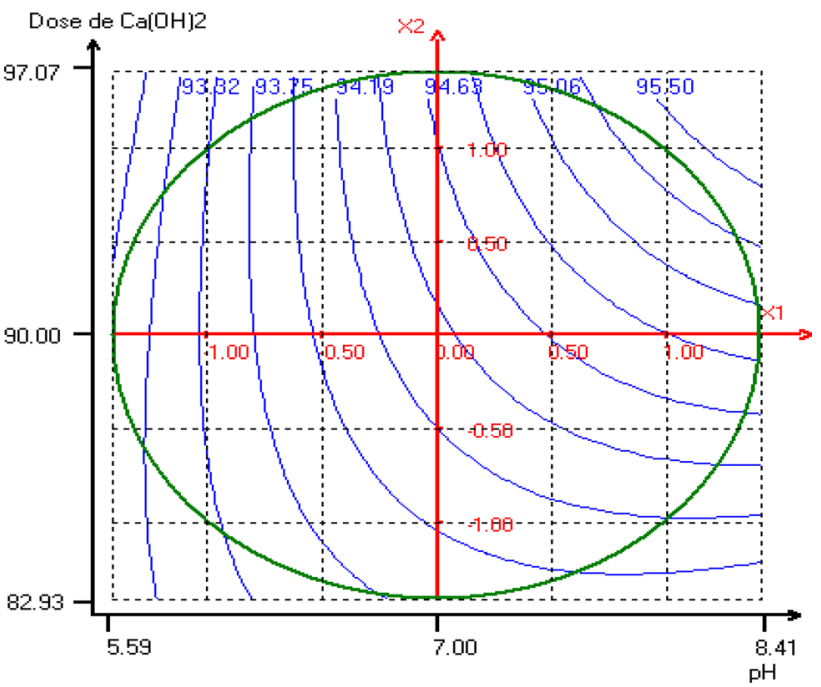

Fig. 3 Change in the response-removal rates in the plan: $\mathrm{pH}, \mathrm{Ca}$ $(\mathrm{OH})_{2}$

Characteristics of the precipitates obtained

In such study, it is important to discuss on the nature of the precipitate obtained. On the basis of results of the literature, it is well known that an excess of lime until a $\mathrm{pH}$ from 9 to 12 led to the precipitation of calcium phosphate, as shown in the following chemical reaction (Degrémont 1989):

$2 \mathrm{Ca}\left(\mathrm{PO}_{4} \mathrm{H}\right)_{2}+\mathrm{Ca}(\mathrm{OH})_{2} \Leftrightarrow \mathrm{Ca}_{3}\left(\mathrm{PO}_{4}\right)_{2}+2 \mathrm{H}_{2} \mathrm{O}$

It is also well known that the solubility of tricalcium phosphate in aqueous solution is very weak, and it remains in colloidal form (Youcef and Achour 2005). It precipitates slowly without the addition of a flocculant (Degrémont 1989). Consequently, it is plausible that the increase in phosphate removal efficiency would be explained by precipitation of $\mathrm{Ca}_{3}\left(\mathrm{PO}_{4}\right)_{2}$. Indeed, according to the results given in Table 4, the final $\mathrm{pH}$ obtained in all cases exceeds 10 . Hydroxyapatite $\mathrm{Ca}_{10}\left(\mathrm{PO}_{4}\right)_{6}(\mathrm{OH})_{2}$ can be formed according to the following reaction (Tchobanoglous et al. 2003):

$10 \mathrm{Ca}^{2+} 6 \mathrm{PO}_{4}^{3-}+2 \mathrm{OH}^{-} \Leftrightarrow \mathrm{Ca}_{10}\left(\mathrm{PO}_{4}\right)_{6}(\mathrm{OH})_{2}$

The products obtained by the use of iron sulfate may be iron hydroxides such as $\mathrm{Fe}(\mathrm{OH})_{3}$. Indeed, the iron phosphates are usually obtained for $\mathrm{pH}$ between 6 and 7 (Molle et al. 2010; Comeau and Ardelain 2006). The scanning electron microscopy (SEM) views reveal that the precipitates present an amorphous and homogenous appearance (SEM images of Fig. 4a, b). 

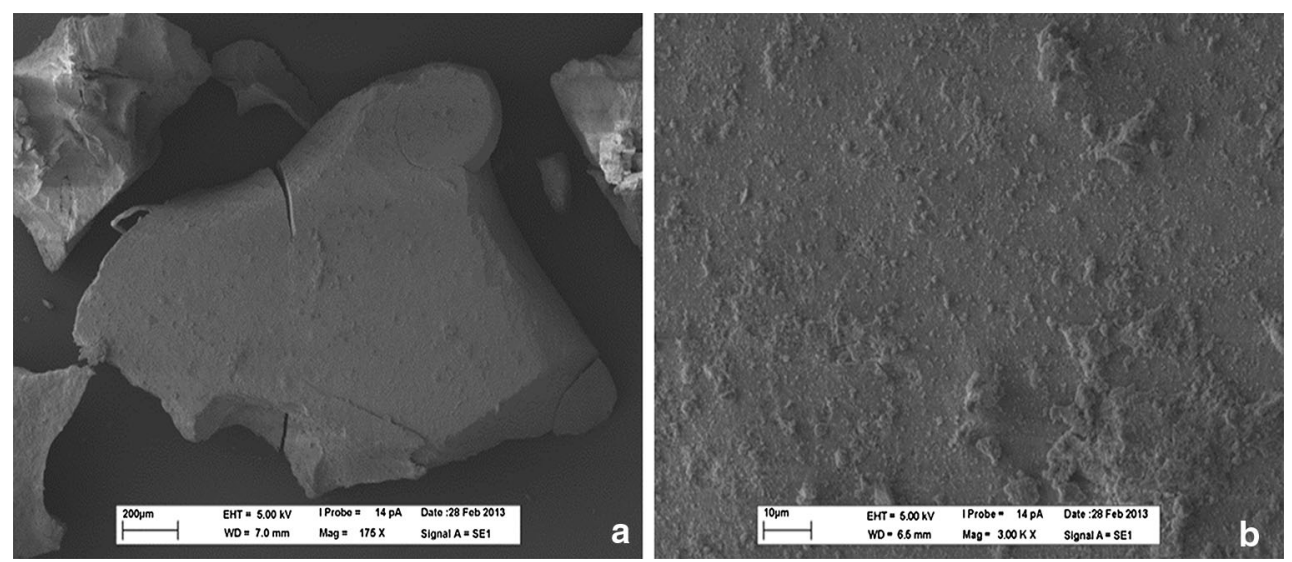

Fig. 4 a SEM macrograph of the precipitate obtained at large scale, b SEM micrograph of the precipitate obtained at small scale

\section{Conclusion}

In this work, the influence of physicochemical parameters on the removal rate in phosphate ions was examined by using an experimental design methodology. This study showed that the $\mathrm{pH}$ and nature of salts (calcium or iron) have a great influence on the phosphate removal rate. It also emerged that the factors such as $\mathrm{pH}$ and hydrated lime are important factors for the co-precipitation of phosphate ions (up to $95.80 \%$ of phosphate could be removed). A second-order mathematical model of the removal of phosphate ions, depending on two parameters which are $\mathrm{pH}$ and $\mathrm{Ca}(\mathrm{OH})_{2}$ concentration $(\mathrm{mg} / \mathrm{L})$, was finally proposed. This model allows us to predict the removal rate in different experimental conditions. Moreover, on the basis on the $\mathrm{pH}$ solution, it was shown that the precipitate formed was hydroxyapatite $\mathrm{Ca}_{10}\left(\mathrm{PO}_{4}\right)_{6}(\mathrm{OH})_{2}$ and the SEM views revealed the amorphous and homogeneous aspect of the precipitates.

Acknowledgments Sincere thanks are extended to the Association of Universities and Colleges of Canada and International Development Research Centre for their financial support.

\section{References}

AFNOR (1994) Essais des Eaux. Dosage des phopsphates, des polyphosphates et du phosphore total (méthode spectrométrique). In: Qualité de l'eau. Association Française de normalisation, Paris

Barbara G, Jarosław W (2005) Removal of phosphates and fluorides from industrial wastewater. Desalination 189:261-268

Battistoni P, Paci B, Fatone F, Pavan P (2006) Phosphorus removal from anaerobic supernatants: start-up and steady-state conditions of a fluidized bed reactor full-scale plant. Ind Eng Chem Res 45:663-669

Biernaux J (1979) Eutrophication and "hypertrophication" of surface waters. Ann Gembloux 85:55-64
CEMAGREF (2004) Phosphorus removal in small active sludge wastewater treatment plants-comparison of technical and economical aspects for biological and physic-chemical phosphorus removal, FNDAE Technical document 29

Comeau Y, Ardelain F (2006) Déphosphatation des boues de la pisciculture des Alléghanys à Saint -Damiende-Buckland par chaulage. SORDAC, Québec. http://www.mapaq.gouv.qc.ca/ siteCollectionDocument/Pecheetaquaculturecommerciales/ SODRAC/36dtt2006_2.pdf

Cordell D, Drangert J-O, White S (2009) The story of phosphorus: global food security and food for thought. Glob Environ Change 19:292-305

Degrémont (1989) Mémento technique de l'eau. Degrémont, Paris, p 1459

Del Nero M, Galindo C, Barillon R, Halter E, Madé B (2010) Surface reactivity of $\alpha-\mathrm{Al}_{2} \mathrm{O}_{3}$ and mechanisms of phosphate sorption: in situ ATR-FTIR spectroscopy and zeta potential studies. J Colloid Interface Sci 342:437-444

Feinberg M (1996) Optimisation de la réponse. In: La validation des méthodes d'analyse-Une approche chimiométrique de l'assurance qualité du laboratoire. Masson, Paris, pp 255-271

GLS (2006) L'élimination du phosphore présent dans les eaux résiduaires urbaines. (Memotec: 23). GLS, Paris. http://www.gls. fr/images/MEMOTEC/Memotec_23.pdf

Goupy J (2006) Les plans d'expériences. Revue Modulad. 34:74-116. http://www.modulad.fr/archives/numero-34/Goupy-34/goupy34.pdf

Hanhoun M, Montastruc L, Azzaro-Pantel C, Biscans B, Freche M, Pibouleau L (2011) Temperature impact assessment on struvite solubility product: a thermodynamic modeling approach. Chem Eng J 167:50-58

Jane Huang C, Liu JC (1999) Precipitate flotation of fluoridecontaining wastewater from a semiconductor manufacturer. Water Res 33:3403-3412

Lupa L, Negrea P, Negrea A, Iovi A, Cocheci L, Mosoarca G (2008) Modelling and automation of the process of phosphate ion removal from waste waters. Braz J Chem Eng 25:9-17

Mama D, Ado G, Yao B (2003) Urban lake system-A case study. J Appl Sci Environ Manage 7:15-21

Molle P, Martin S, Esser D, Besnault S, Morlay C, Harouiya N (2010) Phosphorus removal by the use of apatite in constructed wetlands: design recommendations. 12th IWA's international conference on artificial swamp, Venice (Itay)

Montastruc L (2003) Modelling and optimization of a fluidized bed reactor of phosphorus removal from aqueous effluents, Thesis INP Toulouse 
Roques H (1990) Theoretical foundations of water chemical treatment, vol. II, Ed technical and documentation. Lavoisier, Paris Cedex 08

Said Metahri M (2012) Simultaneous removal of nitrogen and phosphate pollution of wastewater treated by mixed methodscase of step of the city of Tizi-Ouzou. Mouloud Mammeri University of Tizi-Ouzou, Algeria

Shintaro Y, Keisuke F (2012) Removal of phosphate from solution by adsorption and precipitation of calcium phosphate onto monohydrocalcite. J Colloid Interface Sci 384:128-136
Tchobanoglous G, Burton FL, Stensel HD (2003) Wastewater engineering treatment and reuse, 4th edn. McGraw-Hill, NY

Walter T (2010) Experimental design: construction and statistical analysis, mathematics and application. Springer, Berlin

Youcef L, Achour S (2005) Phosphates elimination by physicochemical process. Larhyss J 4:129-140 